\title{
CHANGING PERCEPTIONS OF IDENTITY IN EUROPE AND ITS EFFECTS ON TURKEY'S ACCESSION PROCESS TO THE EUROPEAN UNION
}

\author{
Selin ÖZOĞUZ*
}

\section{Abstract:}

The current enlargement process of the European Union (EU) brought discussions on the European identity into the attention. The progression of unification has recreated perceptions of others and thus also altered the perception of the European identity itself. Concerning Turkey-EU relations, the European identity shift in its self-perception changed also the outlook on Turkey and its membership procedures as a consequence. The important point of discussion that these developments lead us is, whether the EU is a civilizational project with cultural, historical and religious referents or it is a community based on norms and values.

Keywords: Turkey, European Union, identity, values

\section{$\ddot{O}_{\text {zet: }}$}

Avrupa Birliği'ndeki (AB) son zamanlardaki genişleme Avrupalı kimliği konusundaki tartışmalart alevlendirmiştir. $A B$ birleşmesinin gelişmesi diğerlerine olan bakış açısının ve de dolayısı ile Avrupalı kimliğinin sorgulanmasına yol açmıştır. Bu bağlamda, Türkiye- $A B$ ilişkilerine bakılacak olduğunda ise, Avrupalı kimliğindeki değişen algllamalar Türkiye'ye ve Türkiye'nin tam üyelik yoluna olan olan bakış açısında da değişiklikler yaratmıştır. Söz konusu gelişmelerin ışı̆̆ında tartışılması gereken en önemli konu ise AB'nin kültürel, tarihi ve dinsel imlemlere dayanan bir medeniyet mi olduğu veya değerler ve kurallar bütünlüğüne dayanan bir topluluk mu olduğudur.

Anahtar Kelimeler: Türkiye, Avrupa Birliği, kimlik, değerler

"Assist. Prof. Dr., Bahçeşehir University. 


\section{Introduction}

The debates about the European identity, limits of European integration and the criteria to be chosen for their determination have always been an important point. The current enlargement process of the EU brought this topic more into the limelight. The motto "unity in diversity" is commonly seen as the description and aim of the Union, but views differ considerably as to how the concept of identity should be perceived.

In the process of formation of identity, perception is a vital point. Namely, the identity of Europe directly relates to its perception of other states. The process of unification, with the effort to define or construct a European identity and culture, has recreated the perception of others.(Safioleas, 2005: 52) But there are paradoxes concerning the European identity. To an exterior observer, a number of important notions are connected with the idea of European identity. These characteristically include social Europe, Europe as a parameter of democracy and human rights, Christian Europe, and Europe as a global power. It is vital, which of these standpoints will offer a stronger European characterization and which will be considered as relatively weaker or more ambiguous (Öniş, 1999: 108).

Concerning the Turkey - EU relations, steps toward Turkey's unification to the EU have appeared successful thus far, but Europe's changing form, especially the state of affairs after the Cold War, has contributed to some difficulties in this process. Alterations in Europe led to a European identity shift in its self-perception, which also changed the outlook on Turkey as a consequence. By the times of the Cold War the legitimacy of Turkey's application had been fairly well established. From the standpoint of the Turkish politicians and policy-makers, Turkey's full membership in the EU has been considered as an expected step, concluding the process of Westernization, and modernization whose roots could be traced back to the reforms in the early days of the Turkish Republic.

This paper will analyze the perception of identity shifts, both in the EU and Turkey and ask the question of how important the civilizational and cultural parameters of Europeanness are. We will explore whether these parameters should be taken as seriously as the Copenhagen criteria, and how these have an effect on the accession process of Turkey to the EU. 


\section{Change of Perceptions in the European Identity}

One important reason for the discussions of European identity to come forward now is that following the accession of the late member states, there is the fear that the size of the Union might not be manageable, and further integration might jeopardize the efficient functioning of the Union. So the issue of borders of the EU is a worrisome issue. But on the other hand there is the role that EU wants to play in the eastern border. There are also promises that the EU has given to the candidate countries like it has given to Turkey. The question is then on which attributes the EU will put more weight. The Union will have to decide and convince both itself and others, including Turkey, on what should be considered as genuine criteria in order to become a member of the Union. And of course a significant point to be kept in mind is whether these criteria should be applied equally.

At this point there is an important distinction and also confusion in the minds of the people. Namely what should be the basis of Europeanness, what kind of criteria should be chosen as the definition of European identity? On the one hand, as described in the Treaty of the EU as well, there are criteria such as devotion to the principles of democracy, respect for human rights and the rule of law. Policy makers and academics have put these criteria forward as workable parameters. But on the other hand there are issues of culture, religion, geographical location, history, tradition and ethnicity.

In the formation of identity, parameters such as values and norms play obviously a role. Another point that plays a role in the formation of identity is that they are mainly constructed by way of "othering". Namely, in order to understand the "self", "othering" is important. Identities are thought to build on shared experiences, memories and myths, in relation to other collective identities. They are often made-up through the opposition to the identities of the significant others, as the history of conflict often illustrates. But the basis behind these kinds of parameters for Europeanness can easily change depending on the circumstances and their effects on perceptions. (The Identity and Limits of European Integration: A Quest for Credible Criteria, 2004: 23) It is noteworthy to mention that the concept of identity can have positive or negative outcomes depending on the situation. Namely, a stress on identity in the formulation of politics may generate a sense of belonging that may be useful in working out collective decisions, but this stress may also endanger a potentially explosive practice of inclusion and exclusion. (Polat, 2006: 512) 
Actually identity and perception are difficult concepts with which to analyze foreign policy initiatives, but in the case of Europe and Turkey they offer an insightful and interesting exploration. In Europe, as we have already mentioned, the post Cold War period has been a period of alteration in the foreign policy issues. (Safioleas, 2005: 51) With respect to its relations with Turkey, this period of change had its influences as well. Europe's changing form has been a factor of an identity shift, which has affected its perception of itself and relations with Turkey.

The reasons behind the power of perception in international identification are various. There is the mental aloofness which is generated through historically based enmity and the fact that it lasts in the public memory. Other reasons may include the mispresentations in education, historical documentation, the media, politicians, and ruling political parties, or leading lobby groups for their varying concerns. We should also add the fact that perceptions of other states constantly alter depending on circumstances. It is for this reason that perception change is such an important factor in looking at the sociopolitical orientation of any given state or group of states.

Concerning the subject of changing circumstances the end of the Cold War is thought by many analysts and historians to lead in a new era marked by the rejuvenation of aspects of old identities. In the case of the EU there is the rejuvenation of Christianity in the European identity. This goes on the assumption that Christianity is a unified force, which clashes with the religiously and ethnically heterogeneous reality of contemporary European society. (Safioleas, 2005: 51)

In the description of Europeanness, or how Europe wants to define itself, the identification and perception of identity should be considered. Namely, to define oneself, firstly a definition of the others is needed. Accordingly, one way of trying to describe "Europeanness" would be to identify "the other". In that context, the identity shift in the Europe's perception of others was the direct consequence of the end of the Cold War. These perceptions of other states and regions are mostly chaotic and confused. But whether positive or negative, these perceptions are fundamental and affective. First, the "significant other" of the Western Europe for the period of the Cold War, that is, the Eastern Bloc countries, ceased being the other and became "us" or "European". Second, the enlargement process required an effort to create and define a new European identity, a new ground of belonging, 
which to a certain extent involved the rejuvenation of aspects of old identities as we already mentioned, such as that of Christianity, which also may lead to othering in giving a new definition to the self. Third, the perceptions of both the citizens and the policy-makers were affected by the difficulties related to the enlargement and unification process. (The Identity and Limits of European Integration: A Quest for Credible Criteria, 2004: 23) Economic considerations are significant in identification. And this is evident in the discriminatory behavior in various European states and in the attitudes toward immigration.

Accordingly, it can be argued that all that is non-European determines what Europe is. Some authors even argue that the European identity has been reconstructed with ethno-cultural dimensions illuminating who is European and who is not. (The Identity and Limits of European Integration: A Quest for Credible Criteria, 2004: 23) Furthermore, that Europe's unclear boundaries increase the importance of historical, racial, ethnic and cultural factors in constructing identity.

When an identity is stable, perception of others are relatively stable as well, despite the identity dynamics of the other state. In the case of Europe and Turkey, during the Cold War, when the European identity was dictated and stabilized by bipolar strategy, Europe had a consistent perception of Turkey within its Cold War paradigm. Namely, Turkey was an ally in NATO. (Safioleas, 2005: 53) Nevertheless, the collapse of the Soviet Union and the consequent change in the global balance of power, and the unification process of the EU forced the Europeans to readjust themselves to a new perception of identity. In this context Turkey was an associate in trade relations but not a political team member.

A relatively new, unified Europe perceives others in relation to its unification, since unification is at the heart of its identity shift. There are areas considered strategically important within this new unification paradigm. Primary importance lies in Central and Eastern Europe (CEE). In the process of defining what is Europe and who is European, the former Soviet bloc states have been perceived to have met the requirements. These requirements are varied, involving both practical, impractical and fabricated reasoning. But the reasoning behind the requirements for European-ness is less important than the requirements themselves. There is also the fact that they can be arbitrarily changed depending upon the situation and the development of an altered perception. Turkey, in contrast to Eastern Europe, is perceived not to have met the requirement of Europeanness. (Safioleas, 2005: 53) 
Actually the complex relationship between Turkey and the EU has been a source of continuous debate and controversy for many years. The reason for the intensification of this debate was influenced by this latest wave of the EU's enlargement process towards the East, which encompass the CEE countries. When Turkey applied formally in 1987, the legitimacy of Turkey's application had been well established. From the perspective of Turkey, Turkey's full membership in the EU has been considered a natural and inevitable step, concluding the process of Westernization and modernization whose roots can be traced back to Atatürk's reforms in the establishment of the Turkish Republic. (Öniş, 1999: 107)

The objections raised against Turkey's accession claims were explicitly based on economic and political reasons. The cultural criteria, if there were any at that time, were not mentioned as explicitly. The grounds for Turkey for not to be accepted straight away were that its economy was not being stable, that it had various accusations on human rights issues and also that it was hurdling in the area of democratization. The logical consequence of these reasons was that it was achievable for Turkey to be a full member of the Union, if it was successful to establish the necessary economic and political conditions.

At a time when there were again some difficulties to the accession claims of Turkey to the EU, the advance of the CEE countries and the more positive approach the EU had towards these countries requires attention in respect of how Europeanness is perceived in the EU. This also brings out the question whether the EU fundamentally is a civilizational project giving weight on cultural, historical and religious issues rather than being a project which necessitates economic, social and political norms and principles?

At this point it is rather useful to make a comparison between the former Soviet block countries and Turkey. A comparative perspective on CEE and Turkey reveals a number of strong similarities concerning levels of economic development and authoritarian political structures. Actually, in spite of periodic breakdowns, representative democracy has been the norm in Turkey during the post-World War II period, although it was not the experience of the Central and Eastern European countries, which were under the communist rule. However, the EU was much more receptive to the idea of including Central and Eastern European countries, where membership has been seen as an instrument for improving economies as well as strengthening democratic regimes. But ironically, the same 
conditions, economic and political shortcomings, have been considered as obstacles to Turkey's claim to full membership. (Öniş, 1999:107) As Kubicek argues, "If post communist states could enter the EU under the mantra Return to Europe, Turkey has no such advantage, as its European credentials are at the heart of disputes over its prospective membership" (Kubicek, 2005: 67).

The dissimilar approaches applied to the CEE countries and Turkey can be explained by manly two motives. If the first one can be explained by geographical and security reasons, the second one is definitely profound cultural reasons. The cultural similarities between the Western and CEE countries apparently established a closer tie.

As a consequence of these recent developments, the integration and enlargement process of the EU seems to confirm that the Union might be a cultural and civilizational project and that Turkey is not seen as part of the European family.

\section{Impacts of Media and Public Opinion on Identity Perception}

There is yet another very significant aspect that plays a role in identity formation and also which has a considerable affect in policy-making as well. It is public opinion in general and the role of media in particular.

Accordingly, what is of interest at this point is not only the facts about Turkey, but how Turkey is perceived through the media. A person's perception of an event is an expression of how this person interprets the information he or she is given. This interpretation in turn depends on a broad range of cultural, social and individual factors having shaped the perceptions of people. And since these perceptions are important as constituting the basis of our actions, this could have serious consequences for Turkey's application for membership in the EU. This is because popular referenda in some EU member countries, notably France, are likely to influence the outcome of the negotiations. Since popular referenda often are expressions of popular perceptions, the need to clarify some aspects of how perceptions of Turkey are shaped appears necessary. (Svendsen, 2006: 3)

Evidently media plays a crucial role in forming peoples' perceptions. Public perceptions as well as media tales are also products of deep-rooted structures of thought that fill collective narratives in a society. Such discursive structures, as the philosopher Michel Foucault would name them, form our ways of thinking. And they might often give rise to stereotypes. In this perspective, the media's power to create perceptions and their dependence on historically formed stereotypes of Turks, form a complex 
background for how Europeans perceive Turkey and the Turks. (Svendsen, 2006: 3)

On the way how the Europeans public perception of the image of Turkey and Turkish people in general are, it is vital to look at the news on Turkey in the major newspapers of Europe. The European media's presentation seems to have negative connotations in relation to Turkey. Most news from Turkey concerns catastrophes, bomb attacks, bird flu and violations of human rights. This flow of negative news easily overshadows any positive connotation Turkey may have as a stable and peaceful country.

Another important aspect that illustrates many European media's reporting of Turkey is Islam. Turkey is frequently presented as different because a large majority of its population is Muslim. Here, it should be considered that Islam has been demonized in much of the world press since $11^{\text {th }}$ September terrorist attacks and that's why the connotation of Islam is far from positive. In this regard, recent public opinion polls indicate that Islam is one of the main reasons for rejecting Turkish membership in the Union. Although it is difficult to prove a direct link between the media discussions about Islam, which is also often spiced with hints to a global network of Muslim terrorism, and a public opinion expressing its fear of Turkey, a connection between the two aspects of public debate seems to be very likely. As a consequence of these arguments it can be said that the media feeds, as it always has, on bad news. (Svendsen, 2006: 3)

Namely, Valery Giscard d'Estaing, Chairman of the Convention on the Future of Europe, announced to the French newspaper Le Monde, that "Turkey cannot be admitted as a member to the EU, simply because it is Asian." According to Giscard, it would be "the end of the EU if Turkey were ever actually to get in." Turkey's Islamic culture, accompanied by the fact that 95 per cent of the country's land mass is in Asia would hinder such entry. (Tavernise, 2006: 8)

As another European policy-maker, Jose Manuel Barroso, the President of the European Commission suggested in the Süddeutsche Zeitung, 17 December 2004 that "Turkey must win the hearts and minds of the European citizens'." This suggestion was mainly based on the surveys of the European Commission on how the European public perceived Turkey and its membership in the EU. Only 31 percent of the EU citizens are in favor of the EU membership being granted to Turkey, while 55 percent are opposed 
to it. Furthermore, these 55 percent agree with the statement that "the cultural differences between Turkey and the EU Member States are too significant to allow for this accession." (Hülsse, 2006: 309)

The synthesis of the two above mentioned aspects of European media coverage of Turkey, negativity and Islam, give rise to the "othering" of Turkey. In the public opinion, as we have already mentioned, Europeans have a particular need to define themselves in negative opposition to outsiders. This may be why one of the most frequently suggested questions in articles about Turkey is to what extent this country is European.

As a Muslim country, Turkey is perceived as being essentially different, morally, culturally and politically, from other European countries. And this difference not only functions as a line of separation, but it also provides a means to project negative characteristics on to this "other", and distance oneself from one's own shortcomings. (Svendsen, 2006: 4)

Indeed, throughout the European history Turks have persistently been associated with violence, dirtiness and stupidity. Many of these perceptions were nourished by British and French travelogue literature from the 19th century. Thanks to the efforts of Lord Gladstone, in the late 1800 s the Turks were associated with monstrous activities in the Balkan Wars against Christian peoples, and during World War I the massacre of Armenians only contributed to a belief in the so called Turkish savagery. (Kubicek, 2005: 68) This tradition should not be neglected when analyzing contemporary media illustration of Turkey. After all, as Edward Said pointed it out, literature is by no means innocent in the shaping of collective narratives (Said, 2003:27). For the more historically cultivated Europeans, it may remind the image of mass of Ottoman soldiers, for others the link to terrorism may come to mind. Another recurrent expression that occurs both in the press and in academic work on Turkey, is idea that Turkey has a "desire for Europe" (Svendsen, 2006: 4).

Yet it is right to claim that there is a link between these speculations and the current public opposition against Turkish membership? As noted above, it is always hard to prove anything when it comes to a vague concept like "public opinion". Yet again it should also be beard in mind that when asked why they are against Turkish membership, a majority of Europeans state that different religion and culture are important factors. And by constantly returning to the question of compatibility between the Turkish religion and the European identity, the media implicitly continues the "othering" of Turkey. 
There is also the other side of the coin, namely how these reflections affect Turkey and the opinions of Turkish policy-makers and the Turkish public in general. The reservations on the part of the European elites and masses in respect to Turkey's European identity intensified the problems of Turkey's European prospects. EU's indecisiveness on the question of Turkey's belonging to Europe brought uncertainty to the relations. This, in turn, created a huge disappointment in Turkey, a country which identifies itself with its European aspirations. Consequently, comments were made on the double standards employed by the EU originating from its Christian premises. (The Identity and Limits of European Integration: A Quest for Credible Criteria, 2004: 27)

In order to provide an insight into the arguments on Turkey's "Europeanness" and its implications for Turkey-EU relations, however, one ought to explore the significance of such affinity for the Turkish identity construction. Since the establishment of the Turkish Republic, indeed even during the last century of the Ottoman era, Turkey's most notable identity referent has been belonging to Europe, to the West and to the contemporary civilization. According to such discourse, Turkey was a Western oriented, secular state, with a comparatively long and successful experience in multiparty democracy. Therefore, it shared European values, and the EU membership would seal Turkey's belonging to Europe. (The Identity and Limits of European Integration: A Quest for Credible Criteria, 2004: 27)

In fact the Turkish identity encompasses various components; European, Mediterranean, Balkan, Middle Eastern, Asian and these are also blended with the Islamic culture. Whether these different aspects will be seen as a strength, and which ones will be considered as more significant, differs according to the perception of these various elements. During the Cold War era, Turkey's Europeanness was not disputed openly, due to its strategic significance for European security. The impact of the end of Cold War has been profound in that respect both for Turkey and for Europe. Despite Turkey's definition of itself as European and the adoption and incorporation of its culture and traditions, the question remains as to how EuropeanTurkey is. At this point it seems to be more important how the definition and perception of the European side will form itself. To the point that Europeans perceive that the Turks belong to the same family, the accession into the EU could be constantly postponed. 
As far as the international perception of Turkey is concerned, many agree that "from a European perspective, it doesn't really look like a kindred spirit," especially when religious differences are taken into consideration. The cultural and religious questions do lurk in the background, even if they are not said out too loud by the policy-makers. (Hardy, 2003: 10)

The new European identity in the process of being formulated is exclusionary. It is now commonplace to talk about a post modern crisis of identity - a sense of alienation and disorientation that accompanies the decomposition of cultural communities. As old identities decompose, so do their related perceptions of others. A new identity and accompanying negative perception has arisen in Europe with regard to Turkey. As time passes, the results of identity and perception shifts in Europe and Turkey will be better known, defining the future of their regional and global relations. (Safioleas, 2005: 57)

At this point Turkey's European inclination poses a fundamental question for the European Union: is the EU a civilizational project with cultural and religious referents, or is it a community of norms and principles? Is it conceivable for a Muslim country, which is already a NATO member, to become one day a member of the EU?

\section{Suggestions for Future Turkey- European Union Relations}

The arguments we have mentioned in the European identity debate and its perception on Turkey's EU membership diverges often from the two main perspectives: European norms and principles based on economic and political referents and the EU's perceptions of an identity based on culture, geography, history or religion.

Article 6 of the Treaty establishing the EU lays down that the "...Union (is) founded on the principles of liberty, democracy, respect for human rights and fundamental freedoms, and the rule of law, principles which are common to the Member States". Article 49 brings out the procedure for the accession of new members: "Any European State which respects the principles set out in Article 6 may apply to become a member of the Union. It shall address its application to the Council, which shall act unanimously after consulting the Commission and after receiving the assent of the European Parliament, which shall act by an absolute majority of its component members."

Actually Turkey has already gone through this procedure. Its membership application was confirmed as qualifying as a European State. Then all the competent EU institutions approved this candidacy. Following 
several obstacles on the way, this membership process has finally reached the stage of accession negotiations in 2005. (Kaleağası, 2007: 5)

Nevertheless, the approach in Europe questioning the legitimacy of this membership road itself and its own identity shifts provoked an opposition against Turkey in many EU countries. Yet the EU's commitments to Turkey, or any other country, should not depend on shifting political or public moods. Pacta sunt servanda is a principle of European law and a matter of credibility for the EU's positioning in the world. So the EU should follow its promises according to the principles which it had already posed itself. (Kaleağas1, 2007: 5)

Finally, an approach based on common values and norms seems to be the one generally accepted one. Firstly, because it includes the criteria adopted by the Union itself as the Copenhagen criteria and secondly, this approach will ensure maximum diversity and minimum discrimination.

Moreover, an approach based on values would be much more in conformity with the image and message the EU wants to put across to the world, as an entity based on values and norms. States that would conform to particular principles like democracy, respect for human rights, the protection of minorities and the rule of law, freedom and economic liberalism should be included in the integration process.

Turkey and the EU need to initiate a process, which involves challenges for both sides. The challenge for Turkey in that respect would be to strike a balance between distinctive characteristics of the Turkish state and society with the requirements of the new, presumably value-based Europe, and its norms. The challenge for the EU, on the other hand, would be to choose clearly to define its identity on the basis of common norms and principles, objectives and aims, and contribute to Turkey's inclusion in the European project in no uncertain terms. Put in this way, there are no opposing differences between Turkish and European identities; there are only endurable diversities. (The Identity and Limits of European Integration: A Quest for Credible Criteria, 2004: 31)

Apart from that, a solid homogeneity is actually not among the necessary foundations for a community of Europeans. On the contrary, one of the intrinsic attributes of the European identity is diversity, in other words plurality. Indeed, a political project like the EU requires a basic common ground among its participants and, in that context, homogeneity is, to a 
certain extent, indispensable. This homogeneity, however, can only be based on devotion to norms and objectives, and not on any other discriminatory ground. In that context, instead of emphasizing differences between themselves and Turkey, the Europeans should celebrate their ability to realize the potential of the diversity Turkey would bring into the integration process and reveal in their power to attract and transform such a country. Yet, in order to accomplish that overwhelming objective, the EU should give Turkey the right incentive, which would be a more clear and coherent outlook on the accession process. Considering the absolute significance of EU membership for Turkey, the EU has to decide explicitly on Turkey's belonging to the EU. This, in turn, would require the EU to determine its identity referents. (The Identity and Limits of European Integration: A Quest for Credible Criteria, 2004: 31)

Furthermore, to avoid the clash of civilizations the only thing to do is facing reality and properly taking the European Muslim dimension into consideration. The studies carried out in this sphere do point to the same direction as well.

As a result of a study carried out for the European Parliament's Committee on Culture and Education, considering the historical background, the diversity of Islam in Europe requires attention for specific intervention. The legal integration of Muslims is presented as a priority. Again according to the same study appropriate action should be undertaken to allow Muslim communities to fully integrate themselves into the European model of relations between sates and religions. Another major point in this respect is that the European Islam is indeed still affected by the dynamics that exist in the wider Islamic world, despite being carried forward by actors who were born in Europe. Analysis of the problems raised by the presence of Muslim communities in Europe does not confirm the assumptions that Islam is incompatible with democracy in the secular states. (Dasetto, 2007: 3)

There already is an awareness of the broader impact the EU-Turkey relations could take on the rest of the Muslim world. An EU that is open to Turkey would send a message to the troubled Muslim world of today that the West does not consider Islam and democracy incompatible. Offering a provisional date for the start of negotiations is an historic chance for Europe but also for the Muslim world to show that their two great civilisations are not fated always to clash. Indeed, an improvement in Turkey-EU relations might enable the European Union to present itself to its southern periphery as a truly multi-cultural entity that is not anti-Muslim. (Bilgin, 2004: 286) 
Concerning the negative public opinion in Europe, which we have mentioned, the responsibility of the media is important. Namely, the media should not continuously bring out the negative views. In addition, back to Turkey itself, the public ears should not be more sensitive to negative voices than the positive ones. The responsibility on the Turkish side is not to feed the eurosceptic mood. Namely, lately many leading European politicians like, Tony Blair, Romano Prodi, Günter Verheugen and Javier Solana have mentioned on several occasions the importance of Turkey's membership to the EU.

An increase of the degree of rationality in Europe's "Turkey debate" were probably best expressed by Jacques Chirac as the President of the French Republic in one of his last statements: "A Turkey which will be fulfilling the criteria of membership will bring to the EU the critical size that it needs to face the global challenges of the 21st century". In deconstructing this statement we find elements of the equation that will allow the enlargement of the EU's economic, regulatory, political and security areas to Turkey. (Kaleağası, 2007: 5)

As an important matter, the international environment should continue to defend an enlarged European single market and effective political unity. Turkey, which will be ready for EU membership, is expected to contribute to the future success of the European project on several dimensions, playing a crucial role in the wearing down of opposing identities. This might be a way of illustrating the redundancy of the "clash of civilizations" scenarios with Turkey's constructive role in the global arena.

\section{Conclusion}

In terms of Turkey-EU relations the disjunction between the norm based rationale and the identity based rationale is a crucial one. Europe has to choose which one is more important for Turkey's claims. According to the arguments mentioned Turkey may lack many of the historical and religious prerequisites to qualify as utterly European, but it is developing institutional framework and a deeper commitment to principles of democracy and respect of human rights.

The foundations of the EU as a political project ready to embrace all those peoples who stick to democracy, protection of human rights and the rule of law can only be based on a European identity, which is created through the norms. Geographical, religious, cultural, civilizational or 
historical grounds for limiting the European project would undermine the role that the EU wants to play in the global world. The EU should not establish its identity by way of differentiating itself from others on the basis of these rather vague criteria. A policy on exclusionary terms runs against the postmodern character of the EU. Such an approach would only create reinforced opposing identities on the part of the insiders and outsiders alike.

Apparently Turkey's accession to EU will be not as smooth as other countries'. Nevertheless it is more important to promote democracy, respect for human rights, peace and prosperity in the world rather than fostering the cultural differences which will only support the argument of "clash of civilizations". Indeed it will be a bold and positive step to accept Turkey as a member of the European family, in order to encourage the values that brings people together.

\section{References:}

The Identity and Limits of European Integration: A Quest for Credible Criteria, (2004). Ankara Papers, Vol. 11 Issue 1.

Bilgin, Pnar (2004). A Return to 'Civilisational Geopolitics' in the Mediterranean? Changing Geopolitical Images of the European Union and Turkey in the Post-Cold War Era. Geopolitics, Vol. 9 Issue 2.

Dasetto, Felice (2007). The Future of Islam in the European Union. EurActiv.

Hardy, Roger (2003). Islam in Turkey: Odd One Out. BBC News.

Hülsse, Rainer (2006). Cool Turkey: Solving the Image Problem to Secure EU Membership. Mediterranean Politics, Vol. 11 Issue 3.

Kaleağası, Bahadır (2007). Common European Values and Interests are the Basis of Turkey's EU Membership Process. Turkey Watch-EU.

Kubicek, Paul (2005). Turkish Accession to the European Union: Challenges and Opportunities. World Affairs, Vol. 168 Issue 2.

Öniş, Ziya (1999). Turkey, Europe, and Paradoxes of Identity: Perspectives on the International Context of Democratization. Mediterranean Quarterly, Vol. 10 Issue 3.

Polat, Necati (2006). Identity Politics and the Domestic Context of Turkey's European Union Accession. Government \& Opposition, Vol. 41 Issue 4.

Said, Edward W. (2003). Orientalism,London: Penguin Books. 
Safioleas, Penelope D. (2005). Identity Shift and Europe's Changing Perception of Others: Europe, Turkey, and the Issue of SelfIdentification. Online Journal of Peace and Conflict Resolution, Vol.2, Issue 1.

Svendsen, Ellen (2006). The Turks Arrive! - European media and public perceptions of Turkey. Zentrum für Europaeische Integrationsforschung. EU-Turkey-Monitor, Vol.2, No.3.

Tavernise, Sabrina (2006). Allure of Islam Signals a Shift within Turkey. The New York Times, 28. 